\title{
A new species of Ampulicomorpha Ashmead from Eocene French amber, with a list of fossil and extant Embolemidae (Insecta: Hymenoptera) of the world
}

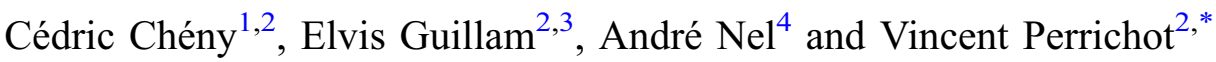 \\ ${ }^{1}$ State Key Laboratory of Palaeobiology and Stratigraphy, Nanjing Institute of Geology and Palaeontology, Chinese Academy of \\ Sciences, No. 39, East Beijing Road, Nanjing 210008, China \\ ${ }^{2}$ Univ Rennes, CNRS, Géosciences Rennes, UMR 6118, 35000 Rennes, France \\ ${ }^{3}$ CR2P, Sorbonne Université - MNHN - CNRS Campus Pierre et Marie Curie, 4 place Jussieu, 75005 Paris, France \\ ${ }^{4}$ Institut de systématique, évolution, biodiversité, ISYEB - UMR 7205-CNRS, MNHN, UPMC, EPHE, Muséum national d'Histoire \\ naturelle, Sorbonne Universités, Université des Antilles, 57 rue Cuvier, CP 50, Entomologie, 75005 Paris, France
}

Received: 15 May 2020 / Accepted: 22 May 2020

\begin{abstract}
Embolemidae is a cosmopolitan but species-poor group of chrysidoid wasps with a scarce fossil record, despite a long evolutionary history since at least the Early Cretaceous. Here, the new species, Ampulicomorpha quesnoyensis sp. nov., is illustrated and described based on a single female found in Early Eocene amber of Oise (France). The new species is compared with the three other known fossil species of the genus, and a key to all fossil species of Ampulicomorpha is provided. This is the third European fossil species of Ampulicomorpha, which suggests that the genus was once well established in Western Europe while it is more widely distributed in the Eastern Palaearctic region today. A list of all fossil and extant Embolemidae of the world, as well as a map of their geographical distribution map, are provided.
\end{abstract}

Keywords: Insecta / Hymenoptera / Chrysidoidea / Paleogene / Oise amber / France

\begin{abstract}
Résumé - Une nouvelle espèce d'Ampulicomorpha Ashmead (Hymenoptera : Chrysidoidea) dans l'ambre éocène de France. Les Embolemidés sont un groupe cosmopolite mais peu diversifié de guêpes chrysidoïdes au registre fossile rare, malgré une longue histoire évolutive depuis au moins le Crétacé inférieur. Une nouvelle espèce, Ampulicomorpha quesnoyensis sp. nov., est illustrée et décrite à partir d'une femelle trouvée dans l'ambre éocène inférieur de l'Oise (France). Elle est comparée aux trois autres espèces connues pour ce genre et une clé des espèces fossiles d'Ampulicomorpha est proposée. Il s'agit de la troisième espèce européenne fossile d'Ampulicomorpha, ce qui suggère que le genre était autrefois bien établi en Europe de l'Ouest alors qu'il est davantage présent dans l'Est de la région Paléarctique aujourd'hui. Une liste des espèces fossiles et actuelles d'Embolemidae du monde ainsi qu'une carte de leur distribution géographique sont aussi proposées.
\end{abstract}

Mots clés : insectes / hyménoptères / chrysidoïdes / Paléogène / ambre de l'Oise / France

\section{Introduction}

Embolemidae is one of the smallest and least known families among Chrysidoidea, currently with 62 extant species described in three genera (see list in Supplementary material: Appendix A): the cosmopolitan Embolemus Westwood, 1833 and Ampulicomorpha Ashmead, 1893; and Trogloembolemus Olmi, Mita and Guglielmino, 2014, which is known only from two troglobitic species from Japan (Mita and Olmi, 2018).

\footnotetext{
* Corresponding author: vincent.perrichot@univ-rennes1.fr
}

Extant embolemid wasps are parasitoids on nymphs of the planthopper families Cixiidae (for Embolemus) and Achilidae (for Ampulicomorpha), but knowledge on their biology remains very limited due to their cryptic behavior and tiny size (varying from 1 to $7 \mathrm{~mm}$ ), making them difficult to find and observe (Olmi, 1995). Within the superfamily Chrysidoidea, Embolemidae has consistently been retrieved as sister to Dryinidae (Brothers and Carpenter, 1993; Carr et al., 2010; Brothers, 2011; Branstetter et al., 2017), although the group has rarely been incorporated in higher-level phylogenies of Hymenoptera to place it in a broader context. 


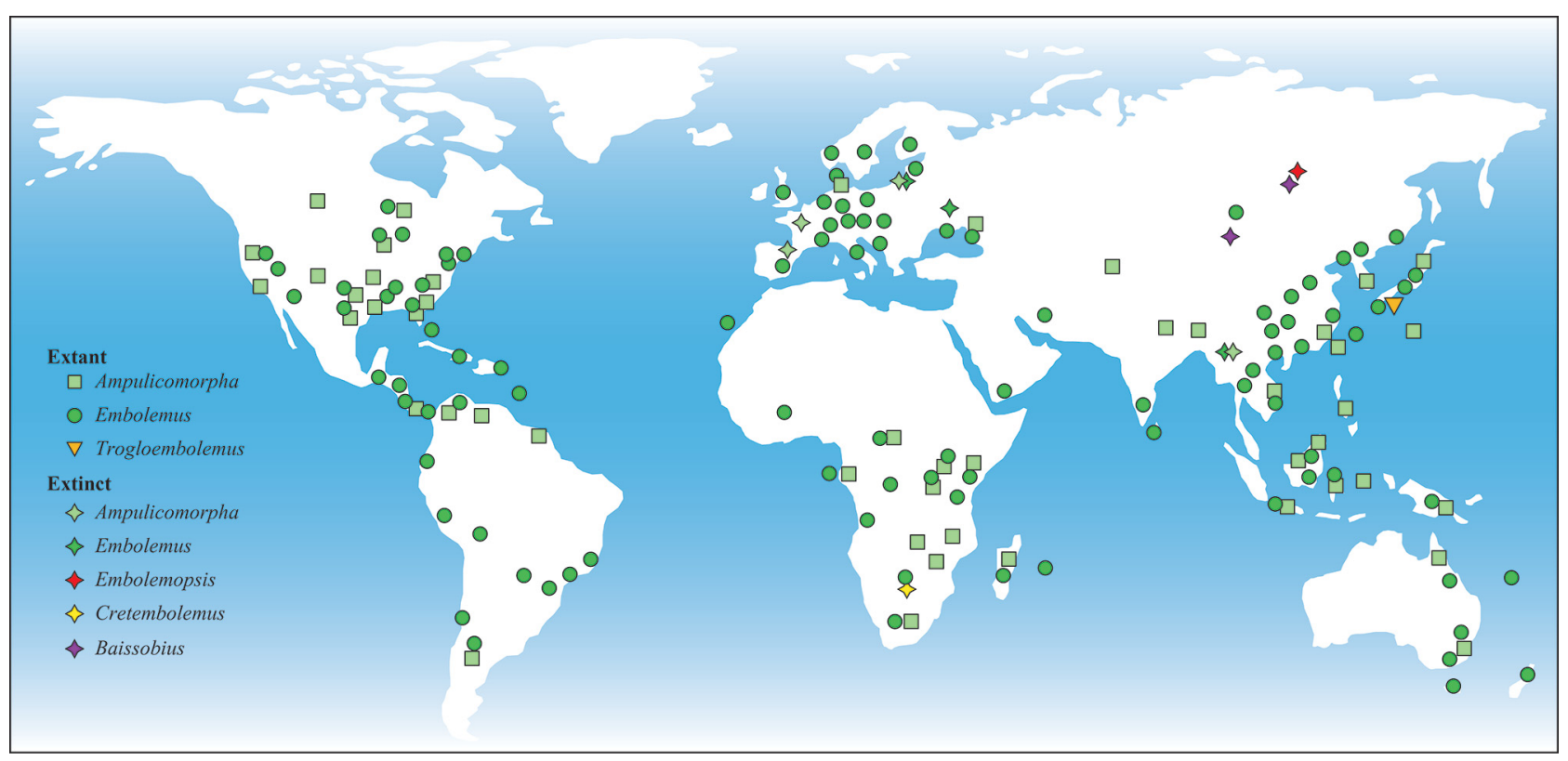

Fig. 1. Distribution of all extant and extinct genera of Embolemidae on a present-day map (data compiled from Olmi, 1995 and all subsequent works on Embolemidae; see Appendix A in Supplementary material).

Morphologically, embolemid wasps are easily discernible from other Chrysidoidea by their 10-segmented antennae that are inserted far from the mouthparts and, in extant genera, on a frontal prominence (but prominence absent in the extinct genera Cretembolemus Olmi, Rasnitsyn, Brothers and Guglielmino, 2014; Baissobius Rasnitsyn, 1975; and Embolemopsis Olmi, Rasnitsyn and Guglielmino, 2010). They are also noticeable for their sexual dimorphism, as several other chrysidoid families, the males being macropterous while females are either micropterous or brachypterous in Embolemus, but macropterous in Ampulicomorpha. The distinction between males of both genera is more challenging, based only on the second cubital cell of the fore wing being closed by distinctly pigmented veins in Ampulicomorpha, and open or closed by weakly pigmented veins in Embolemus. Hence, the synonymy of both genera proposed by van Achterberg and van Kats (2000), which is still controversial as the genera seem to have different hosts and biology and the females are clearly distinct (Olmi et al., 2014c; Contarini et al., 2020). An ongoing molecular analysis of species of both genera will hopefully help clarify this situation (note from M. Olmi in Contarini et al., 2020). Meanwhile, we keep considering Ampulicomorpha as a distinct, valid genus in the present work.

Fossil Embolemidae are known from rock imprints and inclusions in amber but remain infrequent, with only 11 species recognized to date (Fig. 1: eight species from five Cretaceous deposits, three species from two Eocene deposits). But we are aware of a work in progress by Perkovsky et al. (in prep.), in which all known fossil embolemids are reviewed and several new species are described, including new species of Embolemus from mid-Cretaceous Burmese (Kachin) amber as well as the oldest known embolemid, from the Early Barremian amber of the Isle of Wight (ca. 128 Ma). Interestingly, it belongs to the extinct genus Embolemopsis, which is otherwise known only from an Aptian-aged rock imprint from Siberia (Olmi et al., 2010). So far, this is the only genus found both as a rock imprint and an amber inclusion. Other species in rock imprints similarly belong to extinct genera, namely Baissobius and Cretembolemus, while other amber fossils belong to either Embolemus or Ampulicomorpha. Remarkably, these two extant genera are recorded as early as in the mid-Cretaceous, 100-105 Ma (including undescribed species of Embolemus from Kachin amber, pers. obs.). And these Burmese fossils already display a dimorphism similar to extant ones, indicating a long-term morphological stasis in these lineages.

Here we describe a new fossil species of Ampulicomorpha based on a single female specimen from Early Eocene Oise amber, France. This is the second species of Ampulicomorpha from the Eocene of Europe, and the first fossil record of the family Embolemidae in France.

\section{Material and methods}

The description below is based on a single individual found in amber from the Le Quesnoy outcrop, near Houdancourt in the Oise Department of the Paris Basin, France. The outcrop, dated as Ypresian in age ('Sparnacian', Early Eocene, ca. $53 \mathrm{Ma}$ ), has yielded a copious amount of fossiliferous amber associated with abundant plant remains and a diverse vertebrate fauna. Further details on the geology, biodiversity, and paleoenvironment can be found in Nel et al. (1999, 2004), Cavagnetto (2000), Brasero et al. (2009), or Nel and Brasero (2010).

The wasp was found preserved in an automorph, cylindrical piece of orange amber approximately $4.0 \mathrm{~mm}$ in diameter. The piece was partly polished to remove the opaque weathered surface using Buehler CarbiMet silicon carbide papers on a Buehler Metaserv 3000 polisher. Then, it was immersed in Canada balsam between cover slips for optimal views. Observations, measurements, and photographs were made using a Leica MZ APO stereomicroscope equipped with an ocular micrometer and a Canon 5D Mark II SLR camera. 


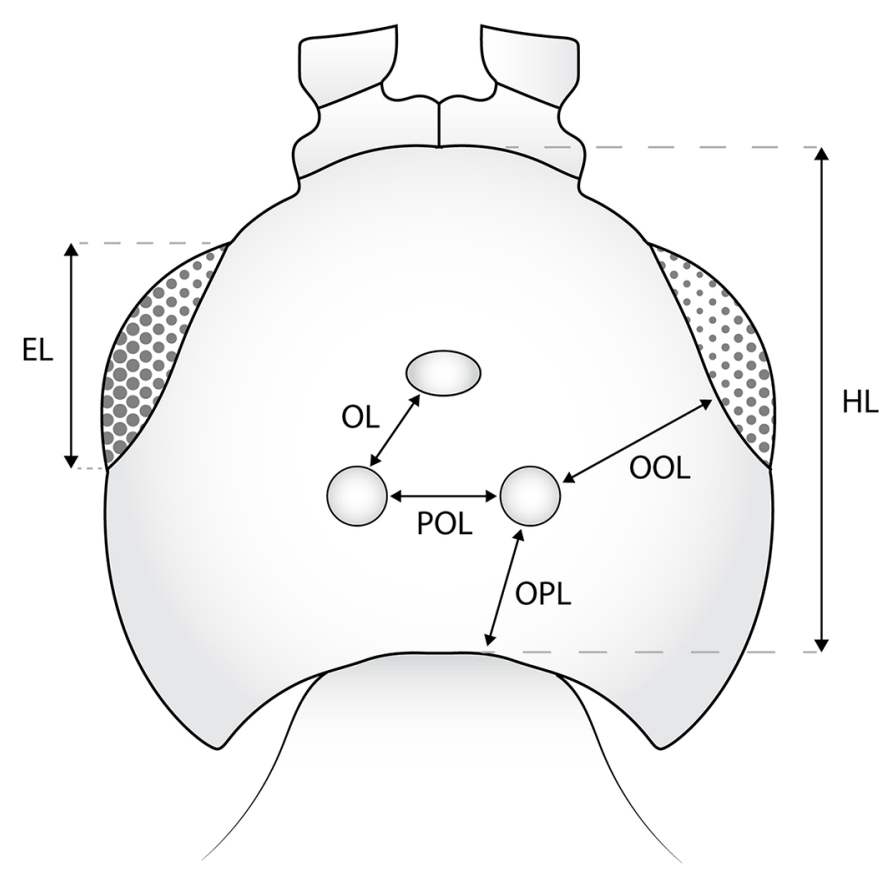

Fig. 2. Schematic line drawing of the head of an embolemid wasp, with indication of measurements used in the present study.

Helicon Focus 6.7 software was used to build composite images from a series of photographs taken at different focal planes. The resulting images and figures were processed using Adobe CC (Photoshop, Illustrator), which was also used to compose the map in Figure 1.

The specimen is preserved without apparent distortion and is mostly complete, missing the tarsomeres of right mid leg, the femoro-tibial articulation of the right hind leg, the left hind leg beyond the femur, the posterodorsal portion of the mesosoma, and most of the wings except basal portions and the apical portion of the right fore and hind wings. The wings and mesosomal structures were apparently lost in an amber splintering that likely occurred during the field collecting or the washing of the amber material.

The terminology used in this study generally follows that of Lanes et al. (2020) pertaining to Bethylidae, with additions of Olmi (1995) or Olmi et al. (2014c) for all the ocellar measurements, which are detailed below with other measurements and indices, and illustrated in Figure 2.

- BL: body length: in dorsal view, median longitudinal line from anteriormost point of frontal projection to posteriormost point of visible gaster ( $\neq$ from gastral apex if apical gastral segments curved ventrally).

- HL: head length: in dorsal view, median longitudinal line from anteriormost point of frontal projection to posterior margin of the occiput.

- EL: eye length: maximum diameter of compound eye measured in oblique lateral view.

- OL: ocellar line: minimum distance between inner margin of lateral ocellus and median (anterior) ocellus.

- OOL: ocular-ocellar line: minimum distance from outer margin of lateral ocellus to compound eye.

- OPL: ocellar-occipital line: minimum distance from posterior edge of lateral ocellus to occipital carina.
- POL: postocellar line: minimum distance between inner margins of lateral ocelli.

This published work and the nomenclatural acts it contains have been registered in ZooBank (http://www.zoobank.org/, last access: 21 May 2020), with the following LSID (reference): urn: lsid:zoobank.org:pub:25DF8ED3-96F9-498A-

BA08-01EE288C15F6.

\section{Systematic palaeontology}

Order HYMENOPTERA Linnaeus, 1758

Suborder APOCRITA Gerstaecker, 1867

Superfamily CHRYSIDOIDEA Latreille, 1802

Family EMBOLEMIDAE Förster, 1856

Genus Ampulicomorpha Ashmead, 1893

Type species Ampulicomorpha confusa Ashmead, 1893: 79. Diagnosis. See Olmi (1995), Olmi et al. (2014a).

Ampulicomorpha quesnoyensis sp. nov.

LSID (species): urn:1sid:zoobank.org:act:B8AC5E69BDC9-4FDC-B22B-B270DE955B39

Figures 3, 4

Holotype. Specimen MNHN.F.A58662, female, housed in the Paleontological collection of the Muséum national d'Histoire naturelle, Paris, France.

Type locality. Le Quesnoy outcrop, Chevrières near Houdancourt, Department of Oise, France.

Type horizon. Lowermost Eocene, Ypresian, biozone MP7 of the reference mammal fauna of Dormaal (= 'Sparnacian', ca. $53 \mathrm{Ma}$ ) (Feugueur, 1963; Nel et al., 1999; Cavagnetto, 2000)

Etymology. The specific epithet is derived from the Le Quesnoy outcrop, the type locality from which the new species originates.

Diagnosis. Antenna with scape approximately $5.4 \times$ as long as pedicel; mesosoma not distinctly elongate (only $1.8 \times$ as long as broad); pronotum with complete median, longitudinal furrow; mesoscuto-scutellar suture medially sulcate, the sulcus bifoveate metasomal petiole elongate, approximately subequal in length to metatrochanter.

Description. Female, macropterous (Fig. 3C: basal portions of all wings and apicalmost portions of the right fore and hind wings are the only preserved parts; but the fore wing reaches the second gastral segment, thus indicating macroptery). Body length $3.15 \mathrm{~mm}$ as visible dorsally (but gaster curved ventrally and anteriorly, total length in lateral view $4.30 \mathrm{~mm}$ ). Head pyriform, slightly longer than high, $0.60 \mathrm{~mm}$ long; eye rather large, higher than long, slightly less than half as long as head $(0.25 \mathrm{~mm}$ long). Antennae filiform, inserted on two contiguous frontal projections; scape elongate, $1.7 \times$ as long as first flagellomere; first flagellomere approximately $2.5 \times$ as long as broad, following flagellomeres gradually shortening except apical one which is longest, with rounded tip; length of antennomeres (in $\mathrm{mm}$ ): $0.65,0.12,0.38,0.35,0.30,0.28$, $0.26,0.26,0.20,0.24$; distance between antennal sockets and clypeus $0.25 \mathrm{~mm}$; ocelli conspicuous, $\mathrm{OL}=0.08$, $\mathrm{OOL}=0.18$, $\mathrm{OPL}=0.24, \mathrm{POL}=0.09$; occipital carina distinct in dorsal and lateral views; mandible tridentate, subrectangular, about twice as long as broad, outer surface slightly convex; maxillary palps with five visible segments, basal segment widest; labial palps not visible. 

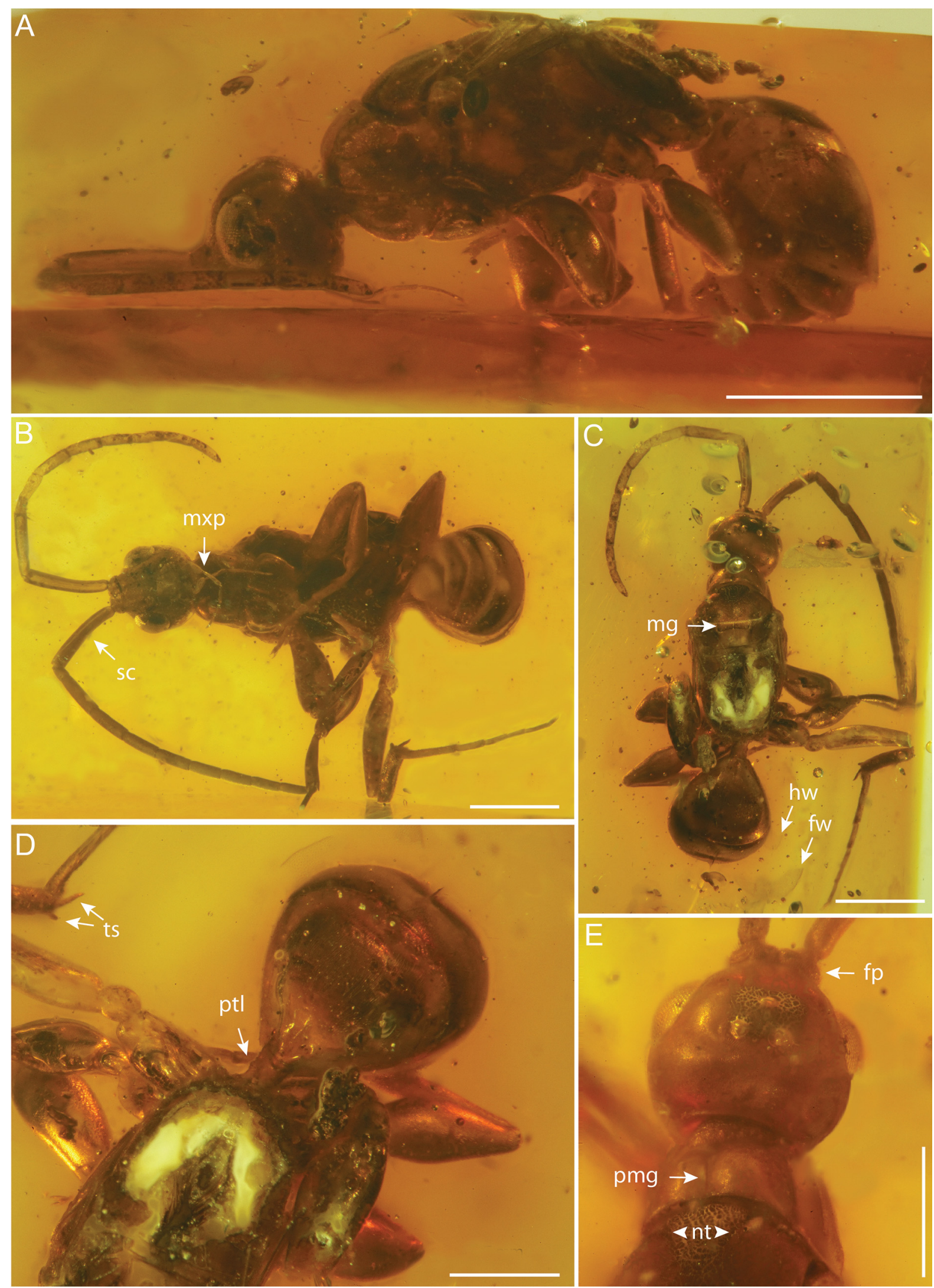

Fig. 3. Ampulicomorpha quesnoyensis sp. nov., holotype MNHN.F.A58662 (female), from Eocene Oise amber (France). A. Habitus in left lateral view. B. Ventral and frontal views, showing maxillary palps (mxp) and scape (sc). C. Dorsal view, showing apex of fore wing (fw) and hind wing (ha), and mesoscuto-scutellar groove (mg). D. Laterodorsal view showing metasomal petiole (ptl) and hind tibial spurs (ts). E. Dorsal view of head, pronotum and mesoscutum, showing contiguous frontal projections (fp), pronotal median groove (pmg), and notauli (ntl). Scale bars: $1 \mathrm{~mm}(\mathrm{~A}, \mathrm{~B}, \mathrm{C}), 0.5 \mathrm{~mm}(\mathrm{D}, \mathrm{E})$. 


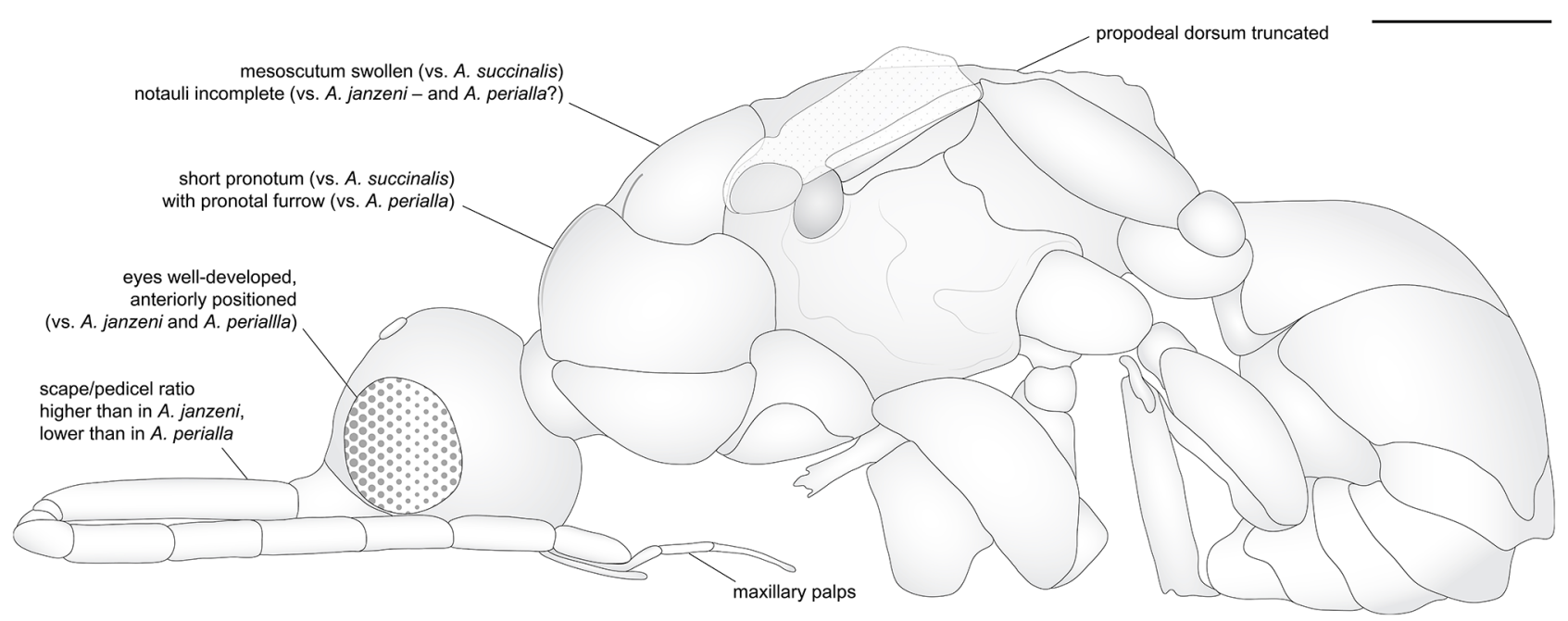

Fig. 4. Ampulicomorphaquesnoyensis sp. nov., holotype MNHN.F.A58662 (female), from Eocene Oise amber (France). Line drawing of the habitus in left lateral view, with indication of the differential characters compared with other fossil species of Ampulicomorpha. Scale bar: 0.5 mm.

Table 1. Comparison of Ampulicomorpha quesnoyensis sp. nov. with other fossil species of Ampulicomorpha (females only).

\begin{tabular}{|c|c|c|c|c|}
\hline & $\begin{array}{l}\text { A. quesnoyensis } \\
\text { sp. nov. }\end{array}$ & A. succinalis & A.janzeni & A. perialla \\
\hline Body length (mm) & 4.3 & $4.1-4.8$ (5.5 in lost holotype) & 2.9 & 3.3 \\
\hline Eye position & Head's anterior half & Head's anterior half & Head's midlength & Head's midlength \\
\hline Scape & $5.4 \times$ pedicel length & $4.85-6 \times$ pedicel length & $3 \times$ pedicel length & $7.25 \times$ pedicel length \\
\hline Pronotal furrow & Complete & Complete & Complete & Absent \\
\hline Fore wing & $\begin{array}{l}\text { Reaching } 2 \text { nd gastral } \\
\text { segment; vein } 2 \mathrm{Cu}-\mathrm{a} \\
\text { not preserved }\end{array}$ & $\begin{array}{l}\text { Surpassing } 2 \mathrm{nd} \\
\text { gastral segment; } \\
\text { vein } 2 \mathrm{Cu}-\mathrm{a} \text { pigmented }\end{array}$ & $\begin{array}{l}\text { Reaching near gastral } \\
\text { apex; vein } 2 \mathrm{Cu}-\mathrm{a} \\
\text { pigmented }\end{array}$ & $\begin{array}{l}\text { Surpassing } 2 \text { nd gastral } \\
\text { segment; vein } 2 \mathrm{Cu}-\mathrm{a} \text { 'nebulous' }\end{array}$ \\
\hline Petiole length & $\begin{array}{l}\text { Subequal to } \\
\text { metatrochanter }\end{array}$ & $\begin{array}{l}\text { Shorter }(0.6 \times) \text { than } \\
\text { metatrochanter }\end{array}$ & $\begin{array}{l}\text { Subequal to } \\
\text { metatrochanter }\end{array}$ & $\begin{array}{l}\text { Shorter to or at most } \\
\text { subequal to metatrochanter }\end{array}$ \\
\hline
\end{tabular}

Data taken from original descriptions, refined descriptions in Perkovsky et al. (in prep.), or personal examination of $A$.janzeni - holotype and additional specimens.

Mesosoma. Moderately elongate, about $1.8 \times$ as long as broad, broadest at level of mesopleura. Pronotum short; in dorsal view, approximately one eighth of mesosomal length, distinctly narrower than remaining mesosoma, with anterior pronotal margin rounded and median longitudinal pronotal furrow complete, not deep. Mesoscutum with notauli incomplete, reaching only near half of mesoscutal length, widely separated posteriorly; faint parapsidal lines not reaching anterior mesoscutal margin. Mesoscuto-scutellar suture medially sulcate, foveate. Metanotum short, transverse. Propodeum mostly missing but sculptured as evidenced by remaining carinae on few preserved lateral and posterior surfaces. Mesopleuron indistinct, apparently unsculptered. Wings almost entirely missing, venation not visible. Legs robust, all femora distinctly swollen; length of metacoxa, metatrochanter, metafemur, metatibia (in $\mathrm{mm})=$ $0.50,0.15$, ca. 0.85 , ca. 0.60 ; tibial spurs $1 / 2 / 2$.
Metasoma. First gastral segment with anterior petiole approximately as long as metatrochanter (ca. $0.16 \mathrm{~mm}$ ); first segment distinctly widening posteriorly, about as long as apical width; second gastral segment largest of metasomal segments; following segments progressively smaller, curved downward, nearly at right angle from first two segments.

\section{Discussion}

Female embolemid wasps typically have the antennal scape elongate, much longer than the third antennal segment (Olmi, 1995), which clearly is the case of the newly described specimen (Figs. 3A-C). The new species, being a macropterous female with the antennae inserted on two contiguous frontal projections, is thus assignable to Ampulicomorpha according to Olmi (1995) or Olmi et al. (2014a). Additionally, the rather large eyes of the new fossil also suggest this genus 
rather than Embolemus, which is characterized by distinctly smaller eyes in females. If the fore wing was preserved, it would likely display a second cubital cell $\left(2 \mathrm{Cu}_{2} \mathrm{c}\right.$ sensu Lanes et al., 2020) fully enclosed by pigmented veins.

The female of the new species differs from those of the two species of Ampulicomorpha described from the Cretaceous, A. perialla (Ortega-Blanco, Delclòs and Engel, 2011) and A.janzeni Olmi, Rasnitsyn, Brothers and Guglielmino, 2014, by its larger size, comparatively larger eyes, and antennal ratios (Tab. 1). The new species is more similar to the Eocene species A. succinalis Brues, 1933, but it differs from it, in females, by its comparatively longer metasomal petiole, longer scape $(5.4 \times$ pedicel length in holotype of $A$. quesnoyensis, $v$. $4.8 \times$ in specimen PIN 964/648 of A. succinalis, which has a similar body length), longer notauli (ca. $0.5 \times$ mesoscutal length, vs. $0.3 \times$ mesoscutal length in A. succinalis), and the presence of a conspicuous, foveate, mesoscuto-scutellar sulcus. Here we propose a key to fossil species of Ampulicomorpha based on females, to accommodate the new species. Unpublished, complemental features of $A$. perialla were kindly provided by Massimo Olmi who reexamined the type specimen for a global review of all fossil Embolemidae.

Key to fossil species of Ampulicomorpha:

1 Antenna with scape more than $7 \times$ longer than pedicel; pronotum without median longitudinal furrow . . . A. perialla (Ortega-Blanco, Delclòs and Engel) (Peñacerrada amber)

- Antenna with scape at most $6 \times$ longer than pedicel; pronotum with complete median longitudinal furrow ... 2

2 Metasomal petiole much shorter than metatrochanter ... A. succinalis Brues (Baltic and Rovno amber)

- Metasomal petiole about as long as metatrochanter . . . 3

3 Body length $2.9 \mathrm{~mm}$; scape $3 \times$ longer than pedicel; notauli complete . . . A.janzeni Olmi, Rasnitsyn, Brothers and Guglielmino (Kachin amber)

- Body length $4.3 \mathrm{~mm}$; scape $5.4 \times$ longer than pedicel; notauli incomplete ... A. quesnoyensis sp. nov. (Oise amber)

\section{Conclusion}

The newly described species of Ampulicomorpha adds to the scant knowledge of the evolutionary history of embolemid wasps. The current fossil record shows that the genus occurred in territories that today belong to the western Palaearctic region from, at least, the late Early Cretaceous (A. perialla from the Albian of Spain) until the Late Eocene (A. succinalis from the Priabonian of the 'Baltic amber forest'). Today, the Palaearctic species of Ampulicomorpha are almost exclusively restricted to its eastern part (Olmi, 1995; Xu et al., 2012; Olmi et al., 2014a; Kim and Lee, 2016; Mita et al., 2017), with the exception of A.thauma Rasnitsyn and Matveev, 1989 in the southwest of Russia (Rasnistyn and Matveev, 1989; Olmi et al., 2014a) and A. reticulata (van Achterberg and van Kats, 2000) in the Netherlands (originally described as Embolemus reticulatus but from a macropterous female, so it has been transferred in Ampulicomorpha by Olmi et al. (2014c) who rejected the synonymy of both genera). In contrast, the only genus broadly distributed today in the western Palaearctic region is Embolemus (Olmi, 1994; Hansen and Olmi, 1996) (Fig. 1).

\section{Supplementary material}

Appendix A: List of fossil and extant Embolemidae of the world.

Appendix B: Supplementary references cited in Appendix A.

The Supplementary Material is available at http://www.bsgf.fr/ $10.1051 / \mathrm{bsgf} / 2020020 / \mathrm{olm}$.

Acknowledgements. We thank Jean-Paul Saint Martin and Simona Saint Martin, $B S G F$ guest editors, for the invitation to contribute to this thematic volume on Amber. We also thank Massimo Olmi (Univ. Tuscia, Italy) for information and bibliography on embolemids; and Massimo Olmi and an anonymous reviewer for their helpful comments on the manuscript. Collection of the amber material was made possible thanks to the Lafarge-Granulat company and the LangloisMeurinne family. This work was partly contributed by C. Chény and E. Guillam during their Master studies, and partial support was provided by Géosciences Rennes through a grant to E. Guillam. Examination of A. janzeni at the SMNS (Stuttgart) was made possible thanks to Karin Wolf-Schwenninger.

\section{References}

Ashmead WH. 1893. Monograph of the North American Proctotrypidae. Bulletin of the United States National Museum 45: 1-472.

Branstetter MG, Danforth BN, Pitts JP, Faircloth BC, Ward PS, Buffington ML, et al. 2017. Phylogenomic insights into the evolution of stinging wasps and the origins of ants and bees. Current Biology 27: 1019-1025. https://doi.org/10.1016/j. cub.2017.03.027.

Brasero N, Nel A, Michez D. 2009. Insects from the Early Eocene amber of Oise (France): diversity and palaeontological significance. Denisia 26: 41-52.

Brothers DJ. 2011. A new Late Cretaceous family of Hymenoptera, and phylogeny of the Plumariidae and Chrysidoidea (Aculeata). ZooKeys 130: 515-542. https://doi.org/10.3897/zoo keys.130.1591.

Brothers DJ, Carpenter JM. 1993. Phylogeny of Aculeata: Chrysidoidea and Vespoidea (Hymenoptera). Journal of Hymenoptera Research 2: 227-304.

Brues CT. 1933. The parasitic Hymenoptera of the Baltic amber. Part I. Bernstein-forschungen 3: 4-178.

Carr M, Young JPW, Mayhew PJ. 2010. Phylogeny of bethylid wasps (Hymenoptera: Bethylidae) inferred from 28S and 16S rRNA genes. Insect Systematics and Evolution 41, 55-73. https://doi.org/ 10.1163/187631210x486995.

Cavagnetto C. 2000. La palynoflore d'un gisement d'ambre de l'Éocène basal du Bassin Parisien (Le Quesnoy, France). Palaeontographica B 255: 147-171.

Contarini M, Olmi M, Capradossi L, Guglielmino A. 2020. Discovery of a new species of Embolemus Westwood (Hymenoptera: Embolemidae) from New Caledonia. Zootaxa 4728: 477-482. https://doi.org/10.11646/zootaxa.4728.4.6.

Feugueur L. 1963. L'Yprésien du bassin de Paris. Essai de monographie stratigraphique. Mémoires de la Carte Géologique de France: 1-568. 
Förster A. 1856. Hymenopterologischer Studien, II. Heft. Chalcidiae und Proctotrupii. Aachen: Ernst ter Meer: 1-152.

Gerstaecker A. 1867. Über die Gattung Oxybelus Latr. und die bei Berlin vorkommenden Arten derselben. Zeitschrift für die Gesammten Naturwissenschaften 30: 1-96.

Hansen LO, Olmi M. 1996. Aculeata of Norway 2. Dryinidae and Embolemidae (Hym., Apocrita). Fauna Norvegica (Series B) 43: 81-88.

Kim CJ, Lee JW. 2016. A review of the family Embolemidae (Hymenoptera: Chrysidoidea) from South Korea. Animal Systematics, Evolution and Diversity 32: 63-71. https://doi.org/10.5635/ ASED.2016.32.2.063.

Lanes GO, Kawada R, Azevedo CO, Brothers DJ. 2020. Revisited morphology applied for systematics of flat wasps (Hymenoptera, Bethylidae). Zootaxa 4752(1): 1-127. https://doi.org/10.11646/ zootaxa.4752.1.1.

Latreille PA. 1802. Histoire naturelle générale et particulière des crustacés et des insectes. Tome 3. Familles naturelles des genres. Paris: F. Dufart.

Linnaeus C. 1758. Systema Naturae per Regna tria Naturae, secundum Classes, Ordines, Genera, Species, cum Characteribus, Differentiis, Synonymis, Locis. Tomus 1. Editio decima, reformata. Holmiae: Laurentii Salvii.

Mita T, Olmi M. 2018. Taxonomic additions of Embolemidae and Sclerogibbidae (Hymenoptera: Chrysidoidea) from Japan, with description of a new species of Trogloembolemus. Zootaxa 4497: 586-592. https://doi.org/10.11646/zootaxa.4497.4.8.

Mita T, Nagano H, Olmi M. 2017. Dryinidae and Embolemidae (Hymenoptera, Chrysidoidea) from Anijima, Ogasawara Islands, Japan. Zootaxa 4323: 239-249. https://doi.org/10.11646/zoo taxa.4323.2.7.

Nel A, Brasero N. Oise amber. In: Penney D, ed. Biodiversity of fossils in amber from the major world deposits. Manchester (UK): Siri Scientific Press, 2010, pp. 137-148.

Nel A, De Ploëg G, Dejax J, Dutheil D, De Franceschi D, et al. 1999. Un gisement sparnacien exceptionnel à plantes, arthropodes et vertébrés (Éocène basal, MP7) : Le Quesnoy (Oise, France). Comptes Rendus de l'Académie des Sciences, Paris, Série IIa 329: 65-72.

Nel A, De Ploëg G, Milliet J, Menier JJ, Waller A. 2004. The French ambers: a general conspectus and the Lowermost Eocene amber deposit of Le Quesnoy in the Paris Basin. Geologica Acta 2: 3-8.
Olmi M. 1994. The Dryinidae and Embolemidae (Hymenoptera: Chrysidoidea) of Fennoscandia and Denmark. Fauna Entomologica Scandinavica 30: 1-100.

Olmi M. 1995. A revision of the world Embolemidae (Hymenoptera Chrysidoidea). Frustula Entomologica 18: 85-146.

Olmi M, Rasnitsyn AP, Guglielmino A. 2010. Revision of rock fossils of Dryinidae and Embolemidae (Hymenoptera: Chrysidoidea). Zootaxa 2499: 21-38. https://doi.org/10.11646/zootaxa.2499.1.2.

Olmi M, Belokobylskij SA, Guglielmino A. 2014a. Revision of the family Embolemidae of Russia and Ukraine (Hymenoptera: Chrysidoidea), with description of a new species. Annales Zoologici 64: 97-108. https://doi.org/10.3161/000345414x680672.

Olmi M, Mita T, Guglielmino A. 2014b. Revision of the Embolemidae of Japan (Hymenoptera: Chrysidoidea), with description of a new genus and two new species. Zootaxa 3793: 423-440. https://doi.org/10.11646/zootaxa.3793.4.2.

Olmi M, Rasnitsyn AP, Brothers DJ, Guglielmino A. 2014c. The first fossil Embolemidae (Hymenoptera: Chrysidoidea) from Burmese amber (Myanmar) and Orapa Kimberlitic deposits (Botswana) and their phylogenetic significance. Journal of Systematic Palaeontology 12: 623-635. https://doi.org/10.1080/14772019.2013.829533.

Ortega-Blanco J, Delclòs X, Engel MS. 2011. The wasp family Embolemidae in Early Cretaceous amber from Spain (Hymenoptera: Chrysidoidea). Journal of the Kansas Entomological Society 84: $36-42$.

Rasnitsyn AP. 1975. Hymenoptera Apocrita of Mesozoic. Trudy Paleontologicheskogo Instituta, Akademii Nauk SSSR 147: 1-134.

Rasnitsyn AP, Matveev DG. 1989. First Palaearctic representative of the genus Ampulicomorpha Ashmead. Entomological Review 69: $133-137$.

van Achterberg C, van Kats RJM. 2000. Revision of the Palaearctic Embolemidae (Hymenoptera). Zoologische Mededelingen 74: 251-269.

Westwood JO. 1833. Descriptions of several new British forms amongst the parasitic hymenopterous insects. London and Edinburgh Philosophical Magazine and Journal of Science 2: 443-445.

Xu Z, Olmi M, Guglielmino A. 2012. A new species of Ampulicomorpha (Hymenoptera: Embolemidae) from China. Florida Entomologist 95: 1187-1191. https://doi.org/10.1653/ 024.095.0450.

Cite this article as: Chény C, Guillam E, Nel A, Perrichot V. 2020. A new species of Ampulicomorpha Ashmead from Eocene French amber, with a list of fossil and extant Embolemidae (Insecta: Hymenoptera) of the world, BSGF - Earth Sciences Bulletin 191: 20. 